ELIEN VAN DE VIJVER, Ph.D.

E-mail: elienvdvijver@gmail.com

BEN DERUDDER, Ph.D.

E-mail: ben.derudder@ugent.be

FRANK WITLOX, Ph.D.

(Corresponding author)

E-mail: frank.witlox@ugent.be

Ghent University, Department of Geography

Krijgslaan 281, S8, 9000 Gent, Belgium
Transport and Sustainable Development

Preliminary Communication

Submitted: Feb. 11, 2015

Accepted: Dec. 1, 2015

\title{
AIR PASSENGER TRANSPORT AND REGIONAL DEVELOPMENT: CAUSE AND EFFECT IN EUROPE
}

\begin{abstract}
This article scrutinizes the mutual and complex causal relationship between air passenger transport and regional development in the European NUTS2-regions with heterogeneous Granger causality analysis between 2002 and 2011. Employment is used as a relatively robust and measurable indicator of a region's development and employment in the services sector and in the manufacturing sector is treated separately to discern basic sectoral variances. The proposed methodology allows investigating (i) if air transport in the European regions causally influences employment, (ii) if employment also leads to higher transport levels, and (iii) regional variations in this causal relationship. The results show that both directions of causality occur among the European urban regions, albeit very geographically fragmented. This indicates that air passenger transport is a necessary part of, but not sufficient condition for generating regional development. The more abundant relationships for employment in the services sector confirm the sensitivity of the services industry to air passenger transport.
\end{abstract}

\section{KEY WORDS}

economic development; air passenger transport; European regional development; Granger causality;

\section{INTRODUCTION}

The aim of the research presented in this paper is to investigate the causal linkages between air passenger transport and regional development - expressed in employment figures - in Europe. Much research on this topic has been carried out for the United States of America (US) [1, 2, 3, 4, 5, 6], but research elsewhere has been lacking. According to Dobruszkes et al. [7], the main reason for this is the difficulty of finding homogeneous data in a multinational context. Moreover, in the US, most of the airports serve a distinct city with limited ground transport options, while, for instance, European airports are surrounded by multiple cities, creating overlapping catchment areas. In the European context, this literature has been limited to Mukka- la and Tervo's analysis [8] of the causal link between air traffic and economic growth, represented by GDP and employment growth, in 86 regions, and Percoco's study [9] on the impact of air passenger transport on the local employment in Italian provinces. The literature often concludes that air passenger transport has a larger influence on economic development than the other way around, although it is obvious that the socio-economic function of a region (e.g. employment and GDP) can equally influence the demand for air passenger transport services $[7,10,11]$.

Despite the limited research in Europe, the European Commission has suggested that air passenger transport is "a strategically important sector that makes a vital contribution to the EU's overall economy and employment' [12]. Against this backdrop, efforts have been made to liberalize the internal air transport market in the European Union in order to unleash the alleged economic benefits associated with the rise in levels of air passenger transport. During a time span of 10 years and via a three-stage process, the European Union (EU) went from a heavily regulated to a liberalized market, culminating in an opening up of the European domestic markets to free competition from all EU-licensed carriers (i.e. cabotage) in 1997 [13, 14, 15]. During this time frame, the European countries also signed increasingly liberal air service agreements with countries outside the European Union, with the Netherlands-USA Open Skies Agreement in 1992 as a pioneering event. These open skies agreements eliminate government involvement in airline decision-making about routes, capacity, and pricing, which contrasts heavily with previous restrictive air service agreements [16]. Since 2005 the EU - as a single aviation market - has tried to extend its uniform aviation policy beyond its borders by negotiating comprehensive agreements to integrate the EU aviation market with those of its key international partners. For example, the EU-US Air Transport Agreement, of which the first phase went 
into effect in 2008, allows any airline of the EU and the United States to fly between any point in the EU and any point in the US. This progressing liberalization of air travel between the EU and its major economic partners has in turn been paralleled by a broader deregulation of the internal air travel market (especially throughout the 1990s), which resulted in increased competition (more airlines, serving more routes), the emergence of low cost carriers (LCC), and lower air fares in the EU. Taken together, these evolutions did not only significantly boost the intra-European air travel, but also the international air travel to and from the European airports $[13,15]$.

The link between air passenger transport and economic development is felt strongly in regional airports, which are the major destinations of the minimal cost-seeking low cost carriers (LCC), because of their lower airport fees, higher availability of airport slots, and absence of traffic congestion [13, 17]. In many cases, the growth in passenger volumes facilitated the economic growth and employment growth and stimulated tourism in the surrounding regions (e.g Donzelli [18] for Southern Italy), effects that can be labelled as the 'catalytic effects' of air transport [19]. At the same time, LCC-related air transport investments to stimulate regional development is not without risks, as this type of airline tends to exhibit a footloose behaviour. Olipra [20], for instance, gives examples from Poland, where LCC-passengers account for more than $90 \%$ of total passengers in some airports (e.g. Katowice, Lodz and Bydgoszcz). Cessation of services from Ryanair or Wizzair on those airports could severely affect the surrounding regions. In a similar vein, in regions that are strongly dependent on tourism, the volatility of air transport connectivity can cause a quick downfall in economic growth and employment levels that are dependent upon tourism.

The major European airports also prospered from the liberalization wave, in which they witnessed larger passenger volumes, thus influencing their surrounding urban and economic landscapes as well [21]. Hakfoort et al. [22], for instance, label the Dutch Amsterdam Schiphol Airport as a 'growth pole' in the regional economy. Multiple case studies have examined the catalytic impacts of European airports on the regional economy (for instance Heuer and Klophaus [23] for Frankfurt-Hahn Airport, and Abraham et al. [24] for Lübeck Airport). These case studies generally emphasise that European airports are vital for the international competitiveness of their wider surrounding region by providing improved accessibility, attracting inward investment, and facilitating trade and tourism [24, 25, 26], and can as such be seen as regional economic motors [21]. However, air passenger transport is endogenous to economic development, as economic development influences air passenger transport in its own right.
In this light, the complex causal relationship between air transportation and employment in European NUTS2-regions with heterogeneous Granger causality analysis will be examined, similar to the work of Tranos [27] on the Internet infrastructure and economic regional development in the European city regions. The proposed methodology makes it possible (i) to investigate if air transport in European NUTS2-regions has a causal influence on employment, (ii) to investigate if employment in those regions also leads to higher transport levels, and (iii) to discern regional variations in this causal relationship. Employment is used here because it is a relatively robust and measurable indicator of a region's economic success [28], and employment in the services sector and employment in the manufacturing sector are treated separately in the analysis to discern basic sectoral variance.

The remainder of the paper is organized as follows. First, the literature on the link between air passenger transport and economic development is reviewed in more detail, followed by a discussion on how the EU uses air passenger transport as a tool for stimulating regional development. Next, the units of analysis are described, the data collection is presented, and the procedure of the heterogeneous Granger causality-methodology is briefly explained. In the following sections, the results of the Granger causality analysis are shown and discussed. The paper concludes with a summary of the results and an overview of avenues for future research.

\section{SOME NOTES ON AIR PASSENGER TRANSPORT AND ECONOMIC DEVELOPMENT}

\subsection{Literature review: link between air passenger transport and economic development}

It is generally assumed that air transport is an enabling factor for wider economic development in a region. Button and Yuan [29: 337], however, state that 'the evidence for this has largely been anecdotal', while Burmeister and Colletis-Wahl [30: 232] warn of the misperceived 'automatic nature' of 'infrastructure effects' which could lead to 'a dangerous vision of infrastructure investment as a universal tool for development strategies'. Vickerman et al. [31: 1] add that 'the precise role of transport infrastructure in the process of regional development, even the direction of causality, is still open to much debate'. Nevertheless, some efforts have been made to shed further light on this complex relationship, mainly within a US context. Table 1 gives an overview of the main analyses within the literature investigating the reciprocal link between 
air passenger transport and employment as an indicator for economic development.

A close reading of Table 1 confirms the overall understanding that air passenger transport and employment in urban regions are positively linked, but additionally highlights three trends: the dominant focus on US metropolitan areas (MAs), the larger influence of air passenger transport on employment, and the emphasis on employment in the services sectors.

Referring to the second trend, a majority of the authors obtain this result by relying on regression-types analyses, where (changes in) air passenger traffic volumes are used to explain (changes in) employment in urban regions. The rationale behind these analyses is the observation that better air transport services imply better accessibility which encourages companies to locate in a region, and stimulate the expansion of the existing businesses [19, 32].
This improved accessibility and connectivity contributes to the economic performance of the wider economy by enhancing its overall level of productivity through increased access to other markets, freer movement of investment capital and workers between regions [25]. Only a number of studies rely on the concept of causality by using regression analyses with lagged variables or Granger causality analyses (e.g. $[3,5,8,39])$. These analyses perceive causality as a chronological precedence of air transport to employment, and some of these studies indicate that employment can also precede air transport services [8, 39].

Referring to the third trend, the focus on employment in the services sector stems from the assumption that the service industry is more sensitive to air passenger transport than other sectors in the economy, because they rely heavily on direct face-to-face contact $[9,34]$. Even with recent technological innovations minimizing the need for interpersonal contact,

Table 1 - Literature on the relationship between air passenger transport and employment

\begin{tabular}{|c|c|c|}
\hline Literature & Region & Results \\
\hline Goetz [33] & US MAs, 1950-1997 & $\begin{array}{l}\text { Positive relation between passengers per capita and both previous and } \\
\text { subsequent levels of employment }\end{array}$ \\
\hline $\begin{array}{l}\text { Debbage [34] } \\
\text { Debbage and Delk [4] }\end{array}$ & $\begin{array}{l}\text { US MAs, } 1973-1995 \\
\text { and } 1973-1996\end{array}$ & $\begin{array}{l}\text { Positive correlation between air services volume and administrative } \\
\text { and auxiliary employment }\end{array}$ \\
\hline Liu et al. [10] & US MAs, 1999 & $\begin{array}{l}\text { \% workforce in professional, services and technical sector (PST) and } \\
\text { management is a predictor for being a major air traffic market }\end{array}$ \\
\hline $\begin{array}{l}\text { Alkaabi and Debbage } \\
\text { [35] }\end{array}$ & US MAs, 1999 & $\begin{array}{l}\text { Linear relationship between number of passenger enplanements, and } \\
\text { employment and number of companies in the PST- and high-technology } \\
\text { sector }\end{array}$ \\
\hline Button and Taylor [36] & US MAs, 1996 & $\begin{array}{l}\text { Link between the quantity and quality of air services to the EU and 'new } \\
\text { employment' (electronics, IT, telecom, management and services...) }\end{array}$ \\
\hline Brueckner [1] & US MAs, 1996 & $\begin{array}{l}\text { Increase in passenger enplanements leads to increase in employment } \\
\text { in services sector, not in the manufacturing sector }\end{array}$ \\
\hline Green [37] & US MAs, 1990-2000 & $\begin{array}{l}\text { Boardings per capita and origin passengers per capita increase employ- } \\
\text { ment growth }\end{array}$ \\
\hline Percoco [9] & $\begin{array}{l}\text { Italian provinces, } \\
2002\end{array}$ & $\begin{array}{l}\text { Significant influence of air passenger transport on employment in the } \\
\text { services sector }\end{array}$ \\
\hline $\begin{array}{l}\text { Blonigen } \\
\text { and Cristea [38] }\end{array}$ & US MAs, 1969 - 1991 & $\begin{array}{l}\text { Annual growth in passenger traffic leads to increase in annual growth in } \\
\text { employment (especially in wholesale and retail-sector) }\end{array}$ \\
\hline Irwin and Kasarda [5] & US MAs, 1950-1980 & $\begin{array}{l}\text { Changes in the structure of the US airline network are a cause rather } \\
\text { than a consequence of employment in manufacturing and producer } \\
\text { services growth }\end{array}$ \\
\hline Ivy et al. [6] & US MAs, 1978-1988 & $\begin{array}{l}\text { Changes in air service connectivity of US metropolitan areas influence } \\
\text { employment levels in administrative and auxiliary sectors (more than } \\
\text { the other direction) }\end{array}$ \\
\hline Neal [39] & US MAs, 2001-2008 & $\begin{array}{l}\text { Number of passengers 'causes' employment in creative sector and vice } \\
\text { versa }\end{array}$ \\
\hline $\begin{array}{l}\text { Button and Lall [2] } \\
\text { Button et al. [3] }\end{array}$ & US MAs, 1994 & $\begin{array}{l}\text { Increases in traffic at hub airports have a positive effect on high-tech } \\
\text { employment. Granger causality in two case study areas indicate causal- } \\
\text { ity from air traffic to employment }\end{array}$ \\
\hline Mukkala and Tervo [8] & $\begin{array}{l}\text { European urban } \\
\text { regions, 1991-2010 }\end{array}$ & $\begin{array}{l}\text { Homogenous Granger causality from employment growth to number of } \\
\text { passengers. Granger causality from air traffic to employment growth in } \\
\text { peripheral regions, but not in core regions }\end{array}$ \\
\hline
\end{tabular}


this direct contact with colleagues, suppliers, customers, and other key employees remains important (e.g. $[40,41,42,43])$. This point came explicitly to the fore in Brueckner [1], who distinguished between employment in the manufacturing and services sector, and found only evidence for a link between air transport and employment in the services sector. Particularly the professional, service and technical (PST) management and high technology sectors seem related to air passenger services $[3,10,35]$. Also, the creative sector, wholesale and retail, and administrative and auxiliary employment have been subject to research [6, 38, 39].

In this paper, previous research has been extended by focusing on the European urban areas and using the methodology of Granger causality to discern causality in the relationship between air transport and employment. Additionally, it is acknowledged that employment in the services sector may be particularly influenced by air traffic, by comparing causality patterns with total employment and employment in the manufacturing sector.

Given that most of the discussion in this paper (and indeed the literature as a whole) focuses on economic development, it is recognized that the used employment indicator has a tangible, yet complex association with economic development more broadly defined. Rather than a construct validity issue per se, in the context of our research, the major potential issue would be uneven temporal responses of employment and air transport volumes to changing macroeconomic conditions. Air transport is a very cyclical industry, i.e. an industry that follows the business cycle so that revenues are higher during economic prosperity and lower during economic contraction. Per capita income, disposable income, and consumer confidence are immediate key drivers of demand for air transport. This is not a crucial problem as it is clear that macro-economic trends have a broadly similar impact on (un)employment, while our methodological approach controls for time trends (see 3.3). However, given its very cyclical nature, air transport demand may well respond more quickly to economic changes than visible in the creation or destruction of jobs, and this may impact our analysis which centers on the suggestion of causality as seen in the timing of change. Given the onset of the economic crisis following the 2007-8 financial crisis (cf. [44]), this may impact the findings reported in this paper.

\subsection{Air transportation as a tool for regional economic development in the European Union}

The EU is, of course, in many different aspects heterogeneous, which is inter alia expressed in large regional economic disparities between but also within countries. One of the prime concerns of regional economic policies is to lower these inequalities, with the particular aim of socio-economic convergence, which involves an equalization of basic incomes promoted by higher GDP growth, competitiveness and employment [45]. Improving accessibility - particularly to remote and less developed regions - is viewed as one possible avenue for facilitating this convergence. In a report for the European Parliament, Dubois et al. [46] acknowledge that access to large markets, extensive and diversified labour markets and advanced services are becoming increasingly important for economic development, but they question the power of improved accessibility for stimulating this development, due to "the lack of scientific evidence on the correlation between transport endowment and the level of economic development' [46: vi].

The assumption of better accessibility improving regional development was used as a starting point for the European Commission to set up the Trans-European Transport Networks (TEN-T) in 1996, a programme to support the construction and upgrade of transport infrastructure across - often peripheral - European regions to reduce the abovementioned large regional socio-economic disparities and to enhance European competitiveness, job creation and cohesion [47]. This is part of the wider system of Trans-European Networks (TENs), including a telecommunications network (eTEN) and a proposed energy network (TEN-E or Ten-Energy). TEN-T envisages coordinated improvements to primary roads, railways, inland waterways, airports, seaports, inland ports and traffic management systems, providing integrated and intermodal long-distance, high-speed routes. Two rounds of funding schemes (2000-2006 and 2007-2013) have already been accomplished, in which also some airports (such as Faro airport, Portugal in 2009) have received funding (http://inea.ec.europa.eu/en/ten-t/ ten-t.htm)

In the framework of its Regional Policy the EU has also established development plans, where part of the focus is on improving accessibility through air traffic, for example in Greece, Lithuania and Poland as indicated in the EU's Operational Programs on 'Improvement of Accessibility', 'Economic Growth' and 'Infrastructure and Environment' (2007-2013). Reflecting the statement of Dubois et al. [46], it is explored to what degree these sorts of programmes and incentives significantly contribute to economic development in European regions by focusing on employment, which is of course only one, but an important dimension of development.

\section{DELINEATION OF THE STUDY AREAS, DATA COLLECTION AND METHODOLOGY}

\subsection{Delineation of the study areas}

Data are collected at the level of European NUTS2-regions, and only those regions for which all the necessary data were available are considered. As well known, NUTS (Nomenclature of territorial units for 
statistics) is developed by the statistical agency of the European Union 'Eurostat' to provide a single uniform breakdown of territorial units for the production of regional statistics [48]. Although it has no legal value per se, it is a powerful tool for comparing European countries and regions. The classification comprises three levels, ranging from countries (level 1) to metropolitan regions (level 3). NUTS level 2 regions are defined as the basic regions for the application of EU regional policies concerning job creation, competitiveness, economic growth, improved quality of life and sustainable development [48]. Their absolute sizes (in terms of population) differ: they constitute provinces, regions or counties, depending on the country to which they belong. In this study, NUTS2-regions are assumed to be the prime catchment areas of airports. Defining catchment areas of airports and linking this to functional catchment areas of airports is, of course, very difficult. The size and shape of catchment areas differ $[49,50]$ and are influenced by various parameters such as the availability of direct connections, the frequency of flights, but also the accessibility of the airport on landside [7]. The overlap between catchment areas and NUTS2-regions is complex, and may include the following possibilities:

1) Some catchment areas are larger than the proposed NUTS2-regions. For example, the actual catchment area of Vienna International Airport in Austria also covers parts of Western Slovakia and Hungary, and Southern Czech Republic [51].

2) NUTS2-regions without an airport are not included in our analysis, although they might be influenced by airports located in adjacent NUTS2-regions. For example, all NUTS2-regions in Belgium are in the sphere of influence of Brussels International Airport, but most of them are not included in our analysis because they do not have an airport in their territory.

3) Overlap may also occur, as nearly two-thirds of European citizens are within two hours' drive of at least two airports [52]. For instance, for residents in the southern parts of the Netherlands, Amsterdam Schiphol Airport and Brussels International Airport are two viable options.

Taken together, it is clear that NUTS2-regions should be above all seen as the best-available proxies for the actual catchment areas of airports, and this may have repercussions for the results of our analysis. Nevertheless, they remain the most convenient divisions, being important units for the European statistical data collection. The selected 112 NUTS2-regions are located in 18 different countries, and for each of them the employment-statistics and the number of passengers are collected for the period 2002-2011. The data are freely available on the Eurostat website (http://epp. eurostat.ec.europa.eu/portal/page/portal/eurostat/ home/).

\subsection{Data collection}

The employment-statistics were retrieved from the Eurostat-database on Labour Statistics. The information in this database is based on the EU Labour Force Survey (EU-LFS), a quarterly household sample survey conducted in all EU Member States and in the European Free Trade Association (EFTA) and Candidate countries.

The database follows the NACE classification, which is a statistical classification of economic activities in the European Community [53], and represents employment in the different economic sectors across the European NUTS-regions. Until 2008, the NACE Rev. 1 version was used, after which there was a shift to an improved and more detailed Rev.2 version. Although small differences in the classification system exist between these two versions of NACE, this poses no major problems, as the changes are similar for all the 112 regions and are rather small. Information is collected about:

1) Total employment (all persons aged 15 and over);

2) Employment in manufacturing (NACE section $C$ for statistics from 2008 onwards, i.e. D for statistics until 2008);

3) Employment in services (NACE sections G-Q). These sections comprise much of the subsectors mentioned in Table 1, such as wholesale and retail trade, transportation and storage, information and communication, professional, scientific and technical activities, financial and insurance activities, administrative and auxiliary activities, but also tourism-related services (accommodation and food service activities).

The passenger data were extracted from the database 'Air transport of passengers by NUTS 2 regions'. These data express the total passengers embarked and disembarked in each region and have been calculated by aggregating data collected at the airport level on the regional level, excluding double counting within each region.

\subsection{Granger causality}

Granger causality tests are widely used methods for empirically examining causal relationships between variables. Causality in this sense refers to a chronological precedence of one variable to another. A variable $X$ (e.g. air passenger transport) is said to 'Granger cause' a variable $Y$ (e.g employment), if taking into account past values of $X$ enables better predictions of $Y$ than based exclusively on past values of $Y$. Variable $X$ does not literally 'cause' $Y$, but rather helps to forecast it which is then taken to be a sign of explanatory power [26].

In this research, the variant of heterogeneous time series cross-section (TSCS) Granger causality testing is used. This method allows for scrutinizing the 112 
NUTS2-regions simultaneously over a given time period (2002-2011), permitting dissimilar causation among the different regions [54], a feature that has often been neglected in other research (e.g. [29]).

The heterogeneous TSCS-Granger model can be expressed as:

$y_{i, t}=a_{i}+\sum_{k=1}^{p} \gamma_{k} y_{i, t-k}+\sum_{k=1}^{p} \beta_{i, k} x_{t-k}+u_{i, t}$

In which $a_{i}$ are the fixed effects, $\gamma_{k}$ and $\beta_{i, k}$ represent the autoregressive and regression coefficients, respectively, $y_{i, t-k}$ and $x_{i, t-k}$ the lagged values of the dependent and independent variables, respectively, $u_{i, t}$ the error term, and $p$ the number of time lags. The latter refers to the time difference which offers the maximum level of 'causality' [54]. The assumption underlying this extension is that the autoregressive coefficient is constant for all cross-sections, while the regression coefficient is constant for all time periods but can vary across the cross-sections, which enables the causal heterogeneity [26].

The heterogeneous TSCS-causality testing procedure consists of three consecutive steps, which have been extensively described in Hurlin and Venet [54], Hood III et al. [56], Tranos [27] and Van De Vijver et al. [26]. The procedure is tested separately for the three relationships (i) passenger volume versus total employment, (ii) passenger volume versus employment in the services sector, and (iii) passenger volume versus employment in the manufacturing sector. The three procedures are performed in two directions, once running from passenger volume to the employment indicator and once running from the employment indicator to the passenger volume. In this way, the two-way influence between employment and air transport is simultaneously measured.

In the first step, the homogeneous non-causality test, the null hypothesis of absence of causality from $X$ (e.g. passenger volume) to $Y$ (e.g. total employment) across all regions is put against the alternative hypothesis of presence of causality for at least one region, and verified with an F-test. If the null hypothesis is rejected, a heterogeneous causality test is performed in the second step. Here, the null hypothesis assumes that the perceived causality is similar for all regions, against an alternative hypothesis of similar causality for only some of the regions. In case of rejection of this null hypothesis, individual causality tests for all the regions are executed in the third and optional step.

This methodology is equally used in Mukkala and Tervo [8] who examine the causal relationship between air transport and economic development (translated in GDP and employment) in 86 regions across Europe. They were able to discern regional variability in this relationship (see Table 1): causality from employment growth to passenger volume is homogeneous, but causality from passenger volume to employment growth is heterogeneous and mainly occurs in peripheral regions. The current paper adds to this study, in that it takes into account total employment, but also distinguishes between employment in the manufacturing and services sector.

\section{RESULTS AND DISCUSSION}

Prior to the Granger analysis, the data series needed to be checked for the possible presence of a time trend, which can cause the Granger tests to produce unreliable results. The logarithm of the initial data did not contain any trend. Additionally, a time lag of one year is set, due to the short time period under study (2002-2011). Alternatively, the Granger tests are also performed with a 2-year time lag, but no causality in step 1 could be detected.

First, the causal relationships between the passenger volumes and total employment are analysed, and then those between passenger volumes and employment in the manufacturing and services sector, in order to test whether Breuckner's [1] statement of air transport only influencing employment in the services sector and not the manufacturing sector holds true in our study.

\subsection{Air passenger transport versus total employment}

The results of the homogeneous non-causality test (step 1) and the heterogeneous causality test (step 2) are shown in Table 2 and indicate that for only a subset of the 112 NUTS2-regions, causality relationships between total employment and the passenger volume can be detected.

Table 2 - Results of the homogeneous non-causality (F1) and the heterogeneous causality test (F2)

\begin{tabular}{|c|c|c|}
\hline Direction & F1-test & F2-test \\
\hline \hline Passengers -> total employment & $1.302 * *$ & $1.223^{*}$ \\
\hline Total employment -> passengers & $2.390 * * *$ & $2.382 * * *$ \\
\hline
\end{tabular}

$* * * p<0.01, * * p<0.05, * p<0.10$

The individual causality tests (the results are available from the authors upon request) reveal that causality is present for about half of the regions (Figure 1). For the majority (43) of the regions, causality runs from the passenger volume in year $t$ to total employment in year $t+1$. This has been confirmed by Irwin and Kasarda's [5: 533] finding that "changes in air transportation have altered the competitive advantages of metropolitan areas, and not vice-versa'. However, this statement can be challenged as well, as 10 regions show this 'reverse' effect, and four show bidirectional causality. This illustrates the ability of our analysis to reveal the regional nuances that lie in the relationship between air transport and employment.

These regional nuances do not show a clear pattern (Figure 1), but some clusters with causality from air transport to employment can be perceived. One 
cluster comprises the central, well-developed German and Austrian regions, which are part of the 'European polygon' (cfr. [7]). There is also a Spanish cluster, where Aragon and Cantabria show bidirectional causality. At the same time, causality is missing in other well-connected areas such as the French and Dutch capital regions, while it is present in peripheral regions - both in terms of geographical location and GDP - such as Malta, Estonia and Vest (Romania).

This shows that accessibility is necessary, but not sufficient, for regional growth [57]. The absence of a link in well-developed and accessible regions could point to the fact that additional gains in accessibility may only bring marginal gains in employment [47]. Another explanation lies in the definition of the catchment areas, the areas in the sphere of influence of particular airports: NUTS2-regions are designated as a proxy, but these do not always coincide with the actual size. In Île de France, for instance, causality is lacking, which may be ascribed to the fact that the catchment area of the Parisian airports actually covers a large part of France, instead of only the NUTS2-region.

This can equally explain the lack of any relationship in other regions with 'national' airports that are labeled as the gateway airport for the country and possesses the majority of international connections, such as Schiphol Airport in Zuid-Holland, whose catchment area actually spans the whole of the Netherlands and parts of Belgium. The large size of these catchment areas is enhanced by the availability of the dense ground transport, such as high-speed railways [7].

\subsection{Air passenger transport versus employment in manufacturing and services sectors}

The results of the homogeneous non-causality tests and the heterogeneous causality tests for both services and manufacturing in Table 3 show that bidirectional causality between air passenger transport and employment is present for the services sector, but

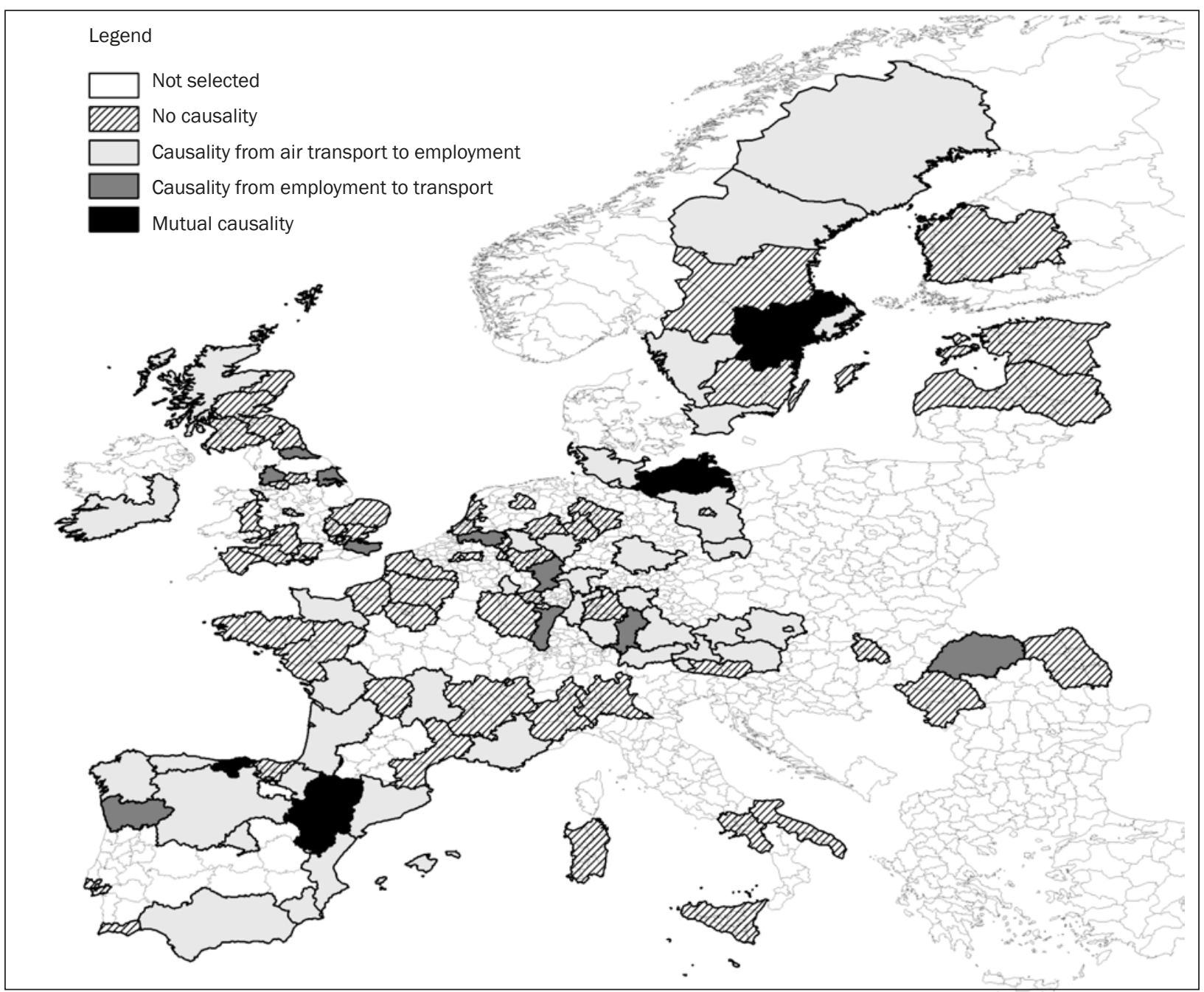

Figure 1 - The different causality relationships between passenger volume and total employment among the 112 NUTS2 European regions 
that causality only runs from air transport to employment in the manufacturing sector.

Table 3 - Results of the homogeneous non-causality (F1) and the heterogeneous causality test (F2)

\begin{tabular}{||c|c|c||}
\hline Direction & F1-test & F2-test \\
\hline \hline Passengers - > services & $2.078 * * *$ & $1.895 * * *$ \\
\hline Services -> passengers & $1.775 * * *$ & $1.726 * * *$ \\
\hline Passengers -> manufacturing & $1.203^{*}$ & $1.194 *$ \\
\hline Manufacturing -> passengers & 0.960 & $/$ \\
\hline
\end{tabular}

$* * * p<0.01, * * p<0.05, * p<0.10$

In other words, the link between air passenger transport and employment in the services sector seems indeed stronger and more abundant: separate analyses for the 112 regions show signs of causality for more than $60 \%$ of the cross-sections (68 NUTS2-regions, Figure 2). The observed trend runs mainly from the number of passengers to employment (52 cross-sections), while causality in the opposite direction holds for only six regions and bidirectional causality occurs for 10 regions. In contradiction with Brueckner [1], Granger causality for the manufacturing sector occurs for a subset of 39 NUTS2-regions (Figure 3), mainly in regions with high levels of manufacturing employment, such as Piemonte and Lombardia in Northern Italy [58]. Other clusters are Scotland and Northern France.

For the link between air passenger transport and employment in the services sector, there is a clear geographical divide. Except for the presence of causality running from air passenger transport to employment in the central European polygon, the abundance of such links frequently holds for the NUTS2-regions in Spain and Southern France. Tourism, which is comprised in our services indicator, possibly plays an important role here. A major part of passengers arriving in South-European regions are tourists stimulating employment in the tourist industry. This is obviously related with the emergence of low-cost carriers (LCCs) after intra-European air transport liberalization [59]. A large part of their networks are clearly designed to

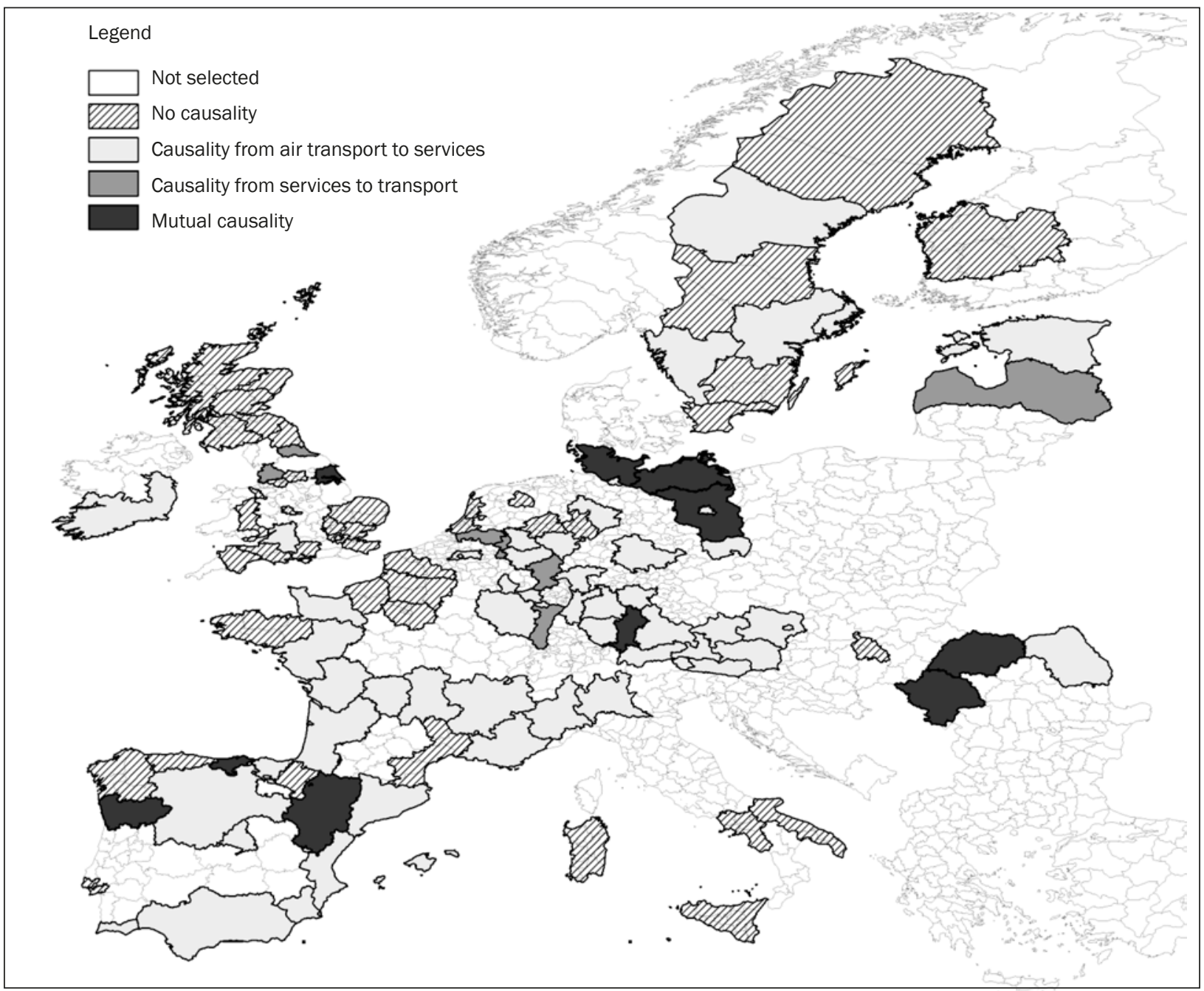

Figure 2 - The different causality relationships between passenger volume and services employment among the 112 European NUTS2-regions 
carry travellers to the tourist destinations of the Mediterranean Europe, such as the Spanish 'costas' [13, 60]. Currently, LCCs increasingly target this business segment [13].

Additionally, LCCs commonly launch new routes on destinations that were previously unavailable or unpopular due to high fares, and the arrival of LCCs in such a region gives a strong initial impulse to tourism. In Barcelona, for instance, there was a considerable increase in passenger arrivals after the entrance of LCCs (Ryanair, Easyjet) into the market in 1996, which was accompanied by a strong increase in hotel room supply [61]. The differences in results for total employment, and employment in the services and manufacturing sector call for caution when interpreting and comparing the results of research that investigates the link between air passenger transport and total employment only [8, 33, 37]. Although this literature offers interesting insights, it says little about how these links are translated for the different sectors of the economy. Employment in the manufacturing and services sector seems to respond differently to air passenger transport, and certainly do not show the same need for generating traffic. This, in addition to the lack of a geographical homogeneity in causality, implies that policy-makers should be cautious when interpreting results with the purpose of formulating policies for the investment in air traffic infrastructure and services for regional (re)development: not all sectors of the economy will be affected in a similar way, just as not all regions are equally affected.

Referring to the European investment programmes, such as TEN-T, the presence of causal links in several peripheral sectors suggest the possible effectiveness of these development and investment programmes. Increased accessibility and connectivity (often through LCCs [62]) in regions that are characterized by relatively lower labour and facilities costs, can encourage companies to invest in those regions and existing business to expand their market [14]. This can in turn stimulate the economic growth potential these regions still possess [45, 47]. However, our results indicate that the causal relationship is not omnipresent in those

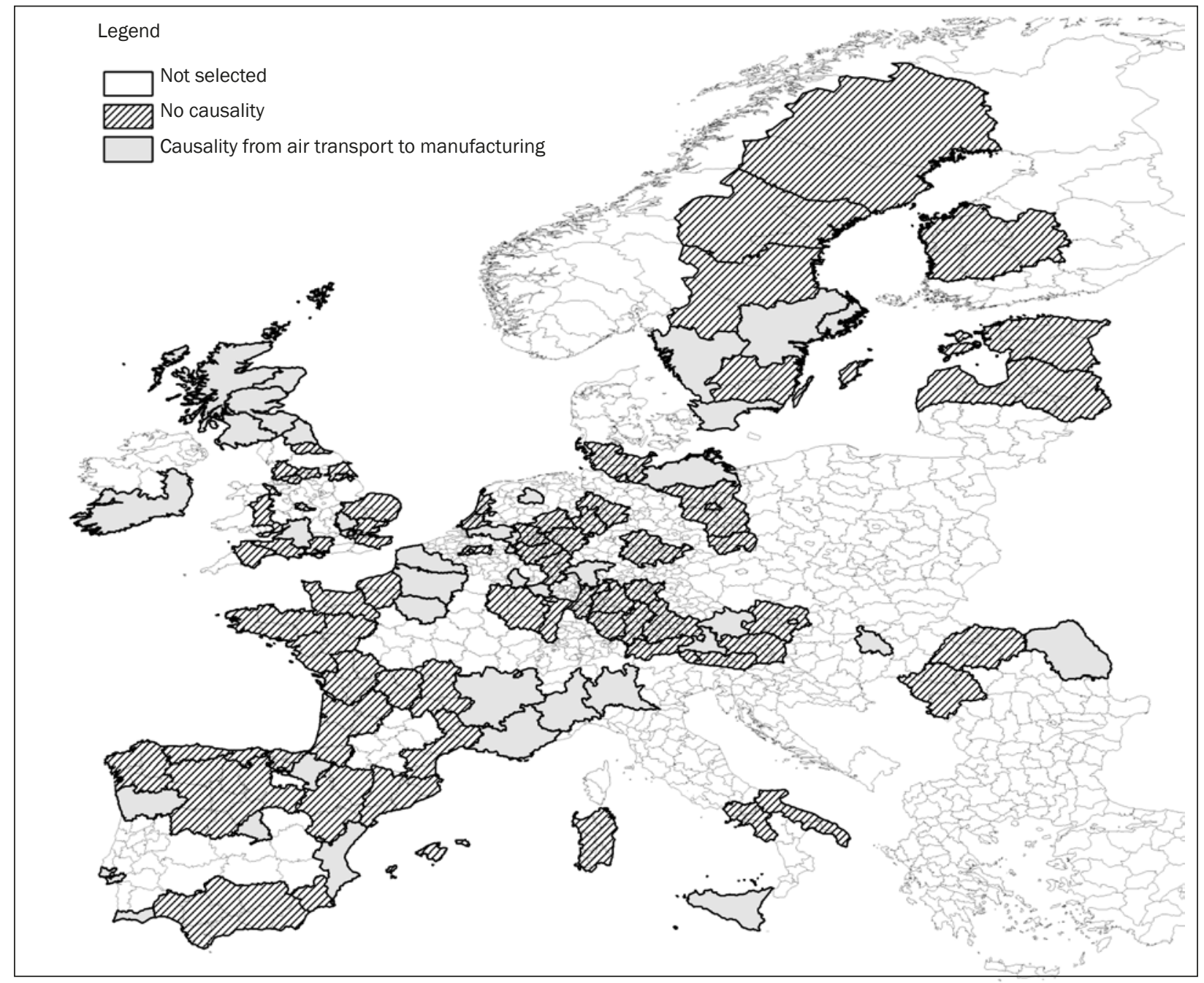

Figure 3 - The different causality relationships between passenger volume and manufacturing employment among the 112 NUTS2-regions 
peripheral regions, and the EU (and national governments alike) should be cautious to set up infrastructure investment programmes with the goal of regional development.

At the same time, it must be noted that air accessibility constitutes only one small part of the total accessibility of European regions [63]. Other transport modes, mainly road and rail transport [47] are also important, as are the internet infrastructures (e.g. [27, 64]), and these are not taken into account in our study. Hence, in agreement with Graham [45], who states that air transport should be viewed as an enabling factor in regional development, overlapping with other transport infrastructures and networks to support European regional development. In this sense, the causality that is proved here does not imply that air transport unconditionally leads to regional development, or that higher employment in regions unequivocally leads to additional generation of air travel. Other factors intervene in the relationship, such as the mentioned presence of other infrastructure, but just as well the population in these regions, or the level of GDP.

\section{CONCLUSION}

This paper has tried to disentangle some of the net causes and effects between air passenger transport and economic development, expressed through passenger volume and employment, in European NUTS2-regions. To this end, heterogeneous Granger causality analysis is used, which allows for statistically assessing causal relationships. In short, our results suggest that (i) the causality patterns between air transport and employment are geographically heterogeneous and sometimes absent, (ii) the influence of air transport on employment is more marked than the influence of employment on air transport, although this direction can also be detected for several regions, and (iii) causality from air transport to employment is stronger for the services sector, but also occurs in the manufacturing sector.

These findings suggest that policy-makers should be careful when advocating infrastructure investment (e.g. by expanding air transport services at airports) as a way of stimulating economic development in a region, as these investments are not always translated into comparable increases in employment. Although there are no clear patterns, it seems that air passenger transport can stimulate growth in employment in some of the peripheral countries, which makes that investment programmes such as those implemented by the EU could bring some benefits.

Our analysis obviously has some limitations. The main limitation of the Granger causality test lies in its bivariate nature, while air passenger transport and economic development are interrelated though a complex web of associations with intervening factors. Future analyses could take these additional factors into account by expanding the analysis to a multivariate framework.

\section{ACKNOWLEDGEMENT}

The authors would like to thank the anonymous reviewers for their comments. The research was funded by the Special Research Fund (BOF) at Ghent University with reference: UGent BOF 01D42810.

ELIEN VAN DE VIJVER, PhD

E-mail: elienvdvijver@gmail.com

voormalig post-doctoraal onderzoekster bij de vakgroep Geografie van de Universiteit Gent

BEN DERUDDER, PhD

E-mail: ben.derudder@ugent.be

FRANK WITLOX, PhD

E-mail: frank.witlox@ugent.be

Vakgroep Geografie, Universiteit Gent

Krijgslaan 281, S8, 9000 Gent, Belgium

\section{SAMENVATTING}

Dit artikel onderzoekt het onderling en complex oorzakelijk verband tussen het luchtvervoer van passagiers en regionale ontwikkeling in de Europese NUTS2-regio's en dit door middel van een Granger causaliteitanalyse tussen 2002 en 2011. De werkgelegenheid wordt gebruikt als een relatief robuuste en meetbare indicator voor de ontwikkeling van een regio, en de werkgelegenheid in de dienstensector en in de sector van de verwerkende industrie wordt apart behandeld om belangrijke sectorale verschillen te kunnen onderscheiden. De voorgestelde methodiek maakt het mogelijk te onderzoeken of (i) het luchtvervoer in de Europese regio's de werkgelegenheid causaal beïnvloedt, (ii) werkgelegenheid ook leidt tot meer vervoer, en (iii) er regionale verschillen te merken zijnin deze causale relatie. De resultaten tonen aan dat beide richtingen van de causaliteit optreden tussen Europese stedelijke regio's, zij het zeer geografisch versnippert. Dit geeft aan dat het luchtvervoer van passagiers een noodzakelijk onderdeel, maar een niet voldoende voorwaarde is voor het genereren van de regionale ontwikkeling. De overvloedige relaties m.b.t. de werkgelegenheid in de dienstensector bevestigen tevens de gevoeligheid van de dienstsector op het luchtvervoer van passagiers.

\section{KERNWOORDEN}

economischeontwikkeling; passagiers/uchtvervoer;Europese regionale ontwikkeling; Granger causaliteit;

\section{REFERENCES}

[1] Brueckner J. Air traffic and urban economic development. Urban Studies. 2003;40(8):1455-1469.

[2] Button K, Lall S. The economics of being an airport hub city. Research in Transportation Economics. 1999;5:75-105.

[3] Button K, Lall S, Stough R, Trice M. High-technology employment and hub airports. Journal of Air Transport Management. 1999;5(1):53-59.

[4] Debbage K, Delk D. The geography of air passenger volume and local employment patterns by U.S. met- 
ropolitan core area: 1973-1996. Journal of Air Transport Management. 2001;7:159-167.

[5] Irwin MD, Kasarda JD. Air passenger linkages and employment growth in U.S. metropolitan areas. American Sociological Review. 1991;56(4):524-537.

[6] Ivy RL, Fik TJ, Malecki EJ. Changes in air service connectivity and employment. Environment and Planning A. $1995 ; 27: 165-179$.

[7] Dobruszkes F, Lennert M, Van Hamme G. An analysis of the determinants of air traffic volume for European metropolitan areas. Journal of Transport Geography. 2011;19(4):755-762.

[8] Mukkala K, Tervo H. Regional airports and regional growth in Europe: which way does the causality run? Environment and Planning A. 2013;45:1508-1520.

[9] [9] Percoco M. Airport activity and local development: Evidence from Italy. Urban Studies. 2010;47(11):24272443.

[10] Liu Z, Debbage K, Blackburn B. Locational determinants of major US air passenger markets by metropolitan area. Journal of Air Transport Management. 2006;12:331-341.

[11] Zuidberg J, Veldhuis J. The role of regional airports in a future transportation system. (Research report 201205, Commissioned by Assembly of European Regions (AER)) Amsterdam: SEO Economic Research; 2012. Available from: http://www.ostsam.no/file $=23550$

[12] European Commission. Air transport. What do we want to achieve? Brussels: European Commission; 2014. Available from: http://ec.europa.eu/transport/ modes/air/index_en.htm.

[13] Dobruszkes F. An analysis of European low-cost airlines and their networks. Journal of Transport Geography. 2006;14:249-264.

[14] ELFAA. Liberalisation of European air transport: The benefits of low fares airlines to consumers, airports, regions and the environment. Brussels: European Low Fares Airline Association; 2004. Available from: http://www.elfaa.com/documents/ELFAABenefitsofLFAs2004.pdf

[15] Scharpenseel MF. Consequences of EU airline deregulation in the context of the global aviation market. Northwestern Journal of International Law \& Business. 2001;22:91-95.

[16] Bowen J. The economic geography of air yransportation: Space, time, and the freedom of the sky. London: Routledge; 2010.

[17] Pavlin S, Dimnik I, Starcevic M. Influence of low-cost carriers on airport infrastructure development. Promet- Traffic \& Transportation. 2007;19(1):49-54

[18] Donzelli M. The effect of low-cost air transportation on the local economy: Evidence from Southern Italy. Journal of Air Transport Management. 2010;16(3):121 126.

[19] Cooper A, Smith P. The economic catalytic effects of air transport in Europe. Final report EEC/SEE/2005/004. Brussel: Eurocontrol; 2005. Available from: http:// www.eurocontrol.int/eec/gallery/content/public/document/eec/report/2005/025_Economic_Catalytic_ Effects_of_Air_Transport_Europe\%20.pdf

[20] Olipra L. The impact of low-cost carriers on tourism development in less famous destinations. Conference proceedings CITTASLOW: il valore della lentezza per il turismo del future; 2012 June 13-14; Perugia/ Orvieto, Italy. Available from: http://www.sinergie- journal.it/index.php?option=com_content\&view=article\&id $=370 \&$ Itemid $=508$

[21] ACl, Airports Council International Europe and York Aviation. The social and economic impacts of airports in Europe. Brussels: ACl and York Aviation; 2004. Available from: https://www.ryanair.com/doc/news/2012/ ACl-Report.pdf

[22] Hakfoort J, Poot T, Rietveld P. The regional economic impact of an airport: The case of Amsterdam Schiphol Airport. Regional Studies. 2001;35(7):595-604.

[23] Heuer K, Klophaus R. Regionalökonomische Bedeutung und Perspektiven des Flughafens Frankfurt-Hahn. Flughafen Frankfurt-Hahn GmbH; 2007. Available from: http://www.hahn-airport.de/sycomax/ files/510767_ATT1032865.pdf

[24] Abraham T, Heising P, Aring J, Klophaus R. Regionalökonomische Auswirkungen: Ausbau Flughafen Lübeck- Regionalökonomische Studie. Im Auftrag der Flughafen Lübeck GmbH. Unterlage B-4. Bonn; 2007. Available from: http://www.ink-schleswig-holstein.de/ linkableblob/swhihk24/standortpolitik/downloads/ sonstiges/737062/.6./data/FlghfLuebeck_Regionaloekonomische_Studie_Kurzfassung-data.pdf

[25] Perovic J. The economic benefits of aviation and performance in the travel \& tourism competitiveness index. In: Blanke J, Chiesa T, editors. The travel \& tourism competitiveness report. Reducing barriers to economic growth and job creation. Genève: World Economic Forum, 2013, p. 57-61. Available from: http:// www3.weforum.org/docs/TTCR/2013/TTCR_Chapter1.4_2013.pdf

[26] Van De Vijver E, Derudder B, Witlox F. Exploring causality in trade and air passenger travel relationships: the case of Asia-Pacific, 1980-2010. Journal of Transport Geography. 2014a;34:142-150.

[27] Tranos E. The causal effect of the Internet infrastructure on the economic development of the European city-regions. Spatial Economic Analysis. 2012;7(3):319-337.

[28] Button K, Taylor S. International air transportation and economic development. Journal of Air Transport Management. 2000;6(4):209-222

[29] Button K, Yuan J. Airfreight transport and economic development: An examination of causality. Urban Studies. 2013;50(2):329-340.

[30] Burmeister A, Colletis-Wahl K. Proximity in production networks: The circulatory dimension. European Urban and Regional Studies. 1997;4:231-241.

[31] Vickerman RW, Spiekermann K, Wegener M. Accessibility and regional development in Europe. Regional Studies. 1999;33:1-15.

[32] Zak D, Getzner M. Economic effects of airports in Central Europe: A critical review of empirical studies and their methodological assumptions. Advances in Economics and Business. 2014;2(2):100-111.

[33] Goetz AR. Air passenger transportation and growth in the U.S. urban system, 1950-1987. Growth and Change. 1992;23:218-242.

[34] Debbage K. Air transportation and urban-economic restructuring: Competitive advantage in the US Carolinas. Journal of Air Transport Management. 1999;5:211-221.

[35] Alkaabi K, Debbage K. Air passenger demand and skilled labor markets by US metropolitan area. Journal of Air Transport Management. 2007; 13(3): 121-130. 
[36] Button K, Taylor S. International air transportation and economic development. Journal of air transport management. 2000; 6(4): 209-222.

[37] Green RK. Airports and economic development. Rea Estate Economics. 2007; 35(1): 91-112.

[38] Blonigen BA and Cristea AD. Air transport and urban growth: Evidence from a quasi-natural policy experiment (Working paper). University of Oregon and NBER; 2012. Available from: http://pages.uoregon.edu/cristea/Research_files/airurban.pdf.

[39] Neal Z. Creative employment and jet set cities: disentangling causal effects. Urban Studies. 2012; 49: 2693-2709.

[40] Bel G, Fageda X. Getting there fast: globalization, intercontinental flights and location of headquarters. Journal of Economic Geography. 2008; 8: 471-495.

[41] Denstadli JM. The impact of videoconferences on business travel: the Norwegian experience. Journal of Air Transport Management. 2004; 10(6): 371-376.

[42] Faulconbridge JR, Beaverstock J, Derudder B, Witlox F. Corporate ecologies of business travel in professional service firms: Working towards a research agenda. European Urban and Regional Studies. 2009; 16: 295308.

[43] Van De Vijver E, Derudder B, Bassens D, Witlox F. Filling some black holes: Modeling the connection between urbanization, infrastructure, and global service intensity. The Professional Geographer. 2014b; 66(1): 82-91.

[44] Derudder B, Witlox, F. The impact of progressive liberalization on the spatiality of airline networks: a measurement framework based on the assessment of hierarchical differentiation. Journal of Transport Geography. 2009; 17(4): 276-284.

[45] Graham B. Liberalization, regional economic development and the geography of demand for air transport in the European Union. Journal of Transport Geography. 1998; 6(2): 87-104.

[46] Dubois A, Gloersen E, Lätheenmäki-Smith K, et al. Regional disparities and cohesion: What strategies for the future? Report to the Directorate General Internal Policies of the Union of the European Parliament. IP/B/REGI/IC/2006_201 14/05/2007. Brussels: European Parliament; 2007. Available from: http:// www.europarl.europa.eu/hearings/20070625/regi/ study_en.pdf

[47] Spiekermann K, Wegener M. Accessibility and spatial development in Europe. Scienze Regionali. 2006; 5(2): 15-46.

[48] European Commission. Regions in the European Union, Nomenclature of territorial units for statistics, NUTS 2010/EU-27 (Eurostat Methodologies and working papers). Luxembourg: Office for Official Publications of the European Communities; 2011. Available from: http://epp.eurostat.ec.europa.eu/cache/ITY OFFPUB/KS-RA-11-011/EN/KS-RA-11-011-EN.PDF.

[49] Lieshout R. Measuring the size of an airport's catchment area. Journal of Transport Geography. 2012; 25: 27-34.
[50] Maertens S. Estimating the market power of airports in their catchment areas - a Europe-wide approach. Journal of Transport Geography. 2012; 22: 10-18.

[51] Sellner R, Nagl P. Air accessibility and growth - The economic effects of a capacity expansion at Vienna International Airport. Journal of Air Transport Management. 2010; 16(6): 325-329.

[52] Thelle M, Pedersen T and Harhoff F. Airport competition in Europe. Copenhagen: Copenhagen Economics; 2012. Available from: http://www.seo.nl/uploads/media/2012-47_Airport_Competition_in_Europe.pdf

[53] European Commission. NACE Rev. 2 - Statistical classification of economic activities in the European Community (Eurostat Methodologies and working papers). Luxembourg: Office for Official Publications of the European Communities; 2008. Available from: http:// epp.eurostat.ec.europa.eu/cache/ITY_OFFPUB/KSRA-07-015/EN/KS-RA-07-015-EN.PDF.

[54] Hurlin C and Venet B. Granger causality tests in panel data models with fixed coefficients (Working paper Eurisco 2001-09). Paris: University of Paris Dauphine; 2001. Available from: http://www.univ-orleans.fr/deg/ masters/ESA/CH/churlin_R.htm

[55] Lütkepohl H, Krätzig M. Applied time series econometrics. Cambridge: University Press; 2004.

[56] Hood MV III, Kidd Q, Morris IL. Two sides of the same coin? Employing Granger causality tests in a time series cross-section framework. Political Analysis. 2008; 16: 324-344.

[57] Nijkamp P. Improving urban environmental quality: Socio-economic possibilities and limits. In: Pernia EM, editor. Urban poverty in Asia: A survey of critical issues. New York: Oxford University Press, 1994, p. 241-285.

[58] Eurostat. Statistics explained: Manufacturing statistics - NACE Rev. 2. Luxembourg: European Commission, Eurostat; 2013. Available from: http://epp.eurostat. ec.europa.eu/statistics_explained/index.php/Manufacturing_statistics_-_NACE_Rev._2

[59] Rey B, Myro R, Galera A. Effect of low-cost airlines on tourism in Spain. A dynamic panel data model. Journal of Air Transport Management. 2011; 17(3): 163-167.

[60] Dobruszkes F. The geography of European low-cost airline networks: a contemporary analysis. Journal of Transport Geography. 2013; 28: 75-88.

[61] Jones Lang Lasalle Hotels. Low cost carriers and their impact on European tourism; 2006. Available from: http://sete.gr/_fileuploads/entries/Online $\% 20$ library/GR/070703_A.IKFocus0n\%20Low\%20 Cost\%20Carriers\%20Nov\%202006.pdf

[62] Airline Network News and Analysis (ANNA). Ryanair launches 20 new routes, mostly to Eastern Europe; 2012. Available from: http://www.anna. aero/2012/11/13/ryanair-launches-20-new-routesmostly-to-eastern-europe/

[63] Allroggen F, Malina R. Do the regional growth effects of air transport differ among airports? Journal of Air Transport Management. 2014; 37: 1-4.

[64] Tranos E, Reggiani A, Nijkamp P. The accessibility of cities in the digital economy. Cities. 2013; 30: 59-67. 